\title{
Osmanlı Kaynaklarına Göre Gedik Ahmed Paşa'nın Kırım Seferi
}

Nur Akbaş

\section{Özet}

II. Murad döneminde iç oğlan olarak Enderun'a intisap eden Gedik Ahmed Paşa, Arnavut asıllı bir devlet adamıdır. Kaynaklarda 1461'den itibaren adı geçmeye başlayan Paşa'nın Larende, Ermenek, Alaiyye ve Silifke'nin zaptında gösterdiği başarılar onun devlet kademelerinde hızla yükselmesine sebep olacaktır. Ayrıca devşirme olması da sarayda baş gösteren rekabette onun lehine olan önemli unsurlardan birisidir. Fatih Sultan Mehmed'in Karadeniz'i bir Türk gölü haline getirme düşüncesi doğrultusunda 1475'de Kırım'a gönderilmiş ve Kefe, Azak, Menkub gibi yörenin önemli şehirlerini zapt etmeyi başarmıştır. Bu arada Kırım Hanlığı da resmen Osmanlılara tabi hale getirilmiştir ki bu hal üç asır devam edecektir.

Esasen Trabzon'un fethiyle Acara bölgesine kadar bütün güney Karadeniz sahilleri Osmanlı'nın eline geçerken Asya, Avrupa ve İskandinavya ile ticarette önemli bir merkez konumunda bulunan Kırım'ın da zaptı kaçınıımaz hale gelmişti. Ayrıca mümbit topraklara da sahip olan Kırım, daha önce CenevizVenedik rekabeti yüzünden her yönden yıpranmıştı. Dolayısıyla bu rekabete de son vermek de gerekiyordu. Neticede uzun bir süredir gelişmeleri sabırla izleyen Fatih Sultan Mehmed, Kırım'da Eminek Bey önderliğinde başlatılan isyanı bahane ederek Gedik Ahmed Paşa vasıtasıyla Basarapya'dan Yabugermen'e kadar Karadeniz'in kuzey sahillerine de hâkim olacaktır.

18 Kasım 1482'de idam edilen Ahmed Paşa'nın Cem Sultan'ın lalalığını yapmış olması hasebiyle II. Bayezid'in gazabına uğradığı yönünde bir görüş mevcut ise de esas meselenin Otlukbeli Muharebesi'nin hemen öncesinde Gedik Ahmed Paşa ile Şehzade II. Bayezid'in aralarında geçen tartışma olmalıdır. $O$ arada ülkenin değişik yerlerinde pek çok hayratın da bânîsi olan Ahmed Paşa, Osmanlı kroniklerinde önemli bir yer işgal eder ve hiç savaş kaybetmemiş paşalardan birisi olarak zikredilir.

Anahtar Kelimeler: Gedik Ahmed Paşa, Fatih Sultan Mehmed, Kırım, Osmanlı.

\footnotetext{
* Doktora Öğrencisi, İnönü Üniversitesi, Sosyal Bilimler Enstitüsü, Tarih Ana Bilim Dalı, nur_akbasss@hotmail.com. (ORCID ID: 0000-0001-7767-9881)

(Makale Gönderim Tarihi: 08.08.2017, Makale Kabul Tarihi: 08.11.2017)
}

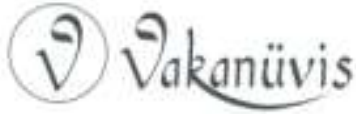




\section{Crimea Campaign of Gedik Ahmed Pasha According to the Ottoman Sources}

\section{Abstract}

Gedik Ahmed Pasha, who entered Enderun as an "içoğlan" in the period of Murat II, is an Albanian -born statesman. After 1461 while Ottomans were captured the Larende, Ermenek, Alaiye and Silifke the pasha's role in this success posses trough sources. So that he rised rapidly in the state levels. Also the fact that he was a devshirme is an important element in favor of the competition, which loom in the palace. Gedik Ahmed Pasha, as the depending of Fatih Sultan Mehmed's desire of turning the Black Sea into becoming a Turkish homeland, was sent to Crimea in 1475 and has succeeded in capturing important cities such as Kefe, Azak, Menkub. Meanwhile, the Crimean Khanate was officially subordinated to the Ottoman Empire, which will continue for three centuries.

Substantially with the conquest of Trabzon, all the southern Black Sea coastal areas up to the Acara region became Ottoman lands, and the capture of the Crimea, which is an important center for trade with Asia, Europe and Scandinavia, became inevitable. In addition, the Crimea, which also has fertile lands, had been quite worn out from all sides because of the GenoeseVenetian rivalry. So it was also necessary to put an end to this competition. As a result, Fatih Sultan Mehmed, who has been following the developments for a long time, has excused there bellion initiated by Eminek Bey in Crimea and by means of Gedik Ahmed Pasha will be com ethe Azak Sea the Turkish lake by rapidly taking other region sun derits control and the North Black Sea coasts from Basarapya to Yabugermen will become Ottoman dominance.

Gedik Ahmed Pasha, executed in 18 November 1482. There is on opinion about this fate that because he had done the "lalalık" of Cem sultan he exposed to II. Bayezid's wroth. But the real issue is that there should be a discussion between Gedik Ahmed Pasha and Şehzade II. Bayezid just before the battle of Otlukbeli. In the meantime, in many places in the country, foundering of the charities Ahmed Pasha, who occupied an important place in the Ottoman chronicles, is one of the pahsas who have never lost their war in their lives according to Ottoman chroniclers.

Keywords: Gedik Ahmed Pasha, Fatih Sultan Mehmed, Crimea, Ottoman.

XV. asrın ikinci yarısında üstün savaşçı yetenekleriyle temayüz etmiş birisi olan Gedik Ahmed Paşa, muhtemelen II. Murad'ın saltanatının ilk yıllarında iç oğlan olarak Edirne sarayına intisap etmiş, Arnavut asıllı bir

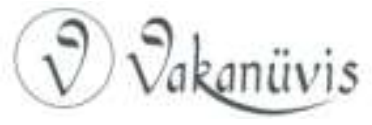


devşirmedir. "Gedik" lakabı ise Âşık Paşazâde'nin Ahmed Paşa için yazdığı bir methiyesinde kale açma, inşa veya tamir etme özelliklerinin vurgulandığı bir beyitte kullanılmıştır. ${ }^{2}$ Zamanla bu lakap Ahmed Paşa ile adeta aynîleşmiş ve bundan böyle $O$, Gedik Ahmed Paşa olarak anılmaya başlanmıştır.

1462 'de İshak Paşa'nın kızı ile evlenerek devlet ricalindeki itibarını iyice artıran Gedik Ahmed Paşa, artık Osmanlı kroniklerinde sürekli söz edilen bir yönetici konumuna yükselmişti. $O$ arada Anadolu Beylerbeyliğ ${ }^{3}{ }^{,}$Vezirlik ${ }^{4}$ ve Veziriazamlık makamlarına getirildiği gibi şehzade Mustafa Çelebi'nin lalalığı da kendisine tevcih edilmiştir. Ancak bu şehzadenin bir müddet sonra ölümü üzerine Şehzade Cem'in lalalığını üstlenecektir. Bu görevi O'nu bütün başarılarına rağmen sürekli şüphelenilen bir devlet adamı haline getirmiştir. 18 Kasım 1482 ' de idam edilmesine de Cem Sultan ile ilişkisinden tedirgin olan II. Bayezid'in bu bağlamdaki endişelerinin gerekçe oluşturduğu şeklinde bilgiler mevcut ise de diğer bazı kaynaklarının ifade ettiği gibi esas sebep Otlukbeli savaşında II. Bayezid'e karşı tavrından ileri gelmiş olmalıdır. ${ }^{5}$

\footnotetext{
${ }^{1}$ Mehmet Süreyya Efendi, Sicill-i Osmânî Yahud Tezkire-i Meşâhir-i Osmâniyye, (nşr., A. Yuvalı, A. Aktan, M. Keskin) İstanbul 1995, s.185; Mükrimin H. Yinanç, "Ahmed Paşa, Gedik", IA I,s. 193vd: Ancak konuyla ilgili Hedda Rendl Kiel, Angiolello'ya dayanarak Gedik Ahmed Paşa'nın Sırbistan'da doğduğunu, İvranye'ye bağlı Polnosevce köyünün 1570 tarihli tahrir defterinde Gedik Ahmed Paşa olarak zikredilmesi hasebiyle doğum yerinin de bu köy olduğunun düşünüldüğünü ifade etmektedir. Ayrıntılı bilgi için bkz; Hedda Reindl Kiel, "Gedik Ahmed Paşa", DiA, XIII, s.543.

2 Âşık Paşazâde, Osmanoğulları Tarihi, (nşr., K. Yavuz-Y. Saraç), İstanbul 2003, s:540; Bu konuyla ilgili J. Von Hammer'in bir dişinin eksikliği sebebiyle verilmiş olduğu yönündeki kaydı pek sarih görülmemektedir. [Bkz., M.H. Yinanç, s.195vd.] "Gedik: Askeri alanda savaşçı sınıfından sayılmadığı halde terfi ederek zabit olabilen topçu ve kale muhafızları gibi askeri sınıfların kadroları için, ayrıca idari alanda Osmanlı sarayında belli bir görev ve imtiyaz manası için kullanılmıştır. Osmanlı hukukunda imtiyaz ve inhisar esasına dayalı tasarruf hakkı anlamında da kullanıldığı vardır." Bkz., Âşık Paşazâde, s.591.

3 Oruç Bey, Tevârîh-i Âl-i Osman, (nşr., N. Öztürk), İstanbul 2008, s.116.

${ }^{4}$ Oruç Bey, a.g.e., s.127; Âşık Paşazâde, a.g.e., s.261; İbn Kemal, Tevârîh-i Âl-î Osman VII, (nşr., Ş. Turan), Ankara 1991, s. 304; İdris-i Bitlisî, Heşt Behişt VII. Ketibe: Fatih Sultan Mehmed Devri, 1451-1481, (nşr., M. i. Yıldırım), Ankara 2013, s.94vd.

${ }^{5}$ Mustafa Çelebi'nin vefatına müteakip Gedik Ahmed Paşa'nın Cem Sultan'ın da lalalığın üstlenmesi Fatih'ten sonra Cem Sultan ile mücadelesinde Bayezid'i, O'nun meselede
}

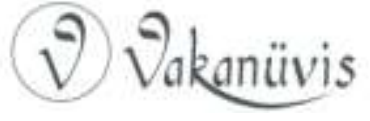


Yeniçeri Ocağı'ndan yetişip de önemli savaşlarda hiç yenilgi almamış birisi olan Gedik Ahmed Paşa ${ }^{6}$ devletin pek çok mühim meselesinde faal bir rol oynamış, ${ }^{7}$ Ayrıca İstanbul başta olmak üzere ülkenin çeşitli yerlerinde yaptırdığı hayratları ile de tanınmış birisidir. ${ }^{8}$

münafıkâne bir tavır alabileceği yönünde tedirginliğine gark etmiş, bu sebeple hapse attırmış ancak kayınpederi İshak ve Hersekzâde paşaların kefaletiyle çıkarılmıştı. Bu olayda devşirme ve Türk kökenli devlet ricali rekabetinin etkisi de görülmektedir. Nitekim Türk bürokrasisinin önemli isimlerinden Karamanî Mehmed ve Hamza Beyoğlu Mustafa Paşa, Gedik Ahmed Paşa aleyhinde Sultan Bayezid'i sürekli tahrik etmekteydi. Ona rağmen İshak Paşa'nın Bayezid'i ikna etmesi üzerine Gedik Ahmed Paşa Cem Sultan'a karşı mücadele için çağıııldığında Karamanî Mehmed'in öldürülmesini istedi ve bu talep kabul gördü. Devşirme olduğu için Gedik Ahmed Paşa yeniçerilerin aşırı sevgisine mazhar olan ve bunu yerinde kullanmayı bilen bir devlet adamıydı. Lakin Cem Sultan'ı kovalarken yakalayamaması ve hakkında yayılan hain olduğuna dair ifadeler Bayezid tarafından infazının sebebi olmuştur.[Bkz., Neşrî, Kitâb-ı Cihan-Nüma, (nşr., M. A. Köymen- F. R. Unat) Ankara 1995, s.817;Oruç Bey, s.236; ibn Kemal, s.357vd.; Hoca Sadettin Efendi, Tacü't-Tevârih III, (nşr., i. Parmaksızoğlu), Ankara 1992, s.130.] Halkın ve yeniçerilerin tepkisinden çekinildiğinden Edirne'de katledildiğine dair bkz., İsmail Hakkı Uzunçarşılı, "Değerli Vezir Gedik Ahmed Paşa II. Bayezid Tarafından Niçin Katledildi?",Belleten XXIX/115, (Temmuz 1965), s.; 491-500; M. H. Yinanç, s.197vd.

${ }^{6}$ Askeri faaliyeti ilk defa II. Mehmed döneminde Anadolu beylerbeyi olarak görülmektedir. İlk askeri başarısını İstanbul fethinin tamamlayıcısı mahiyetinde olan Trabzon fethi meselesinde Koyulhisar'da göstermiştir. [Bu husustaki ayrıntılar için bkz., Neşrî, a.g.e., s. 749; Âşık Paşazâde, a.g.e., s. 254-259; ibn Kemal, a.g.e., s.382vd.] Gedik Ahmed Paşa gerek Sinop, gerek Koyulhisar seferine iştirak etmiştir. Bununla birlikte Uzun Hasan'ın amcası Hurşid Bey ile Erzincan'da bir muharebeye girişmiş ve başarılı olmuştur. Bu durumdan korkan Uzun Hasan ise validesi Sare Hatun'u elçilik etmesi için II. Mehmed'e göndermiştir. Gedik Ahmed Paşa, Karaman seferi akabinde buraya vali olarak gönderilen şehzade Mustafa Çelebi'ye lala tayin edilmiş, 1471 yılında daha evvel Rum Mehmed Paşa'ya verilip, başarısızlıkla sonuçlanan Eğriboz seferiyle görevlendirilmiş ve bu görevin de hakkını vererek galip gelmiştir. Ahmed Paşa'nın bu zaferini İçel ve Karaman'daki Silifke, Mokan, Gorigos, Gülek ve Lülye fetihleri takip etmiştir. Ayrıntılı bilgi için bkz.,Tursun Bey, Târih-i Ebu'l-Feth, (nşr., M. Tulum), İstanbul 1977, s.149-153; Hadîdî, Tevârih-i Âl-i Osman, (nşr., N. Öztürk) İstanbul 1991, s.257vd.; Hoca Sadettin Efendi, a.g.e., s.140.

${ }^{7}$ Uzun süredir devleti hayli zorlayan Akkoyunlu beyi Uzun Hasan, yurtlarını geri almak isteyen Karaman oğullarıyla birleşerek onlara askeri yardımda bulunmuşsa da muvaffak olamamıştır. Daha sonra Uzun Hasan'ın Karamanoğlu Kasım Bey'e yardım göndererek Tokat'ı talan etmesi ve bu duruma Osmanlı kuvvetlerince mukavemet gösterilememesi üzerine II. Mehmed İstanbul'da Mahmud, Gedik Ahmed ve Mustafa paşaları meşveret etmek üzere toplamıştır. Gedik Ahmed Paşa, Sultan'a bir kulunu akıncılarla gönderip ilk önce Tokat'ın intikamının alınmasını ve bunun üzerine vereceği tepkisine göre hareket etmenin makul olacağını önermiş ve bu öneri kabul görüp,

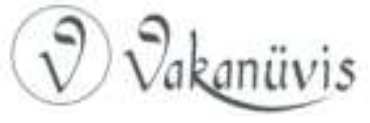


Sultan II. Mehmed, İstanbul'un fethinden sonra Anadolu'nun önemli bir kısmını da kontrol altına almıştı. Özellikle Karamanoğullarının ${ }^{9}$ itaat altına alınması, arkasından da Uzun Hasan gailesinin bertaraf edilmesi Osmanlı Sultanı'nın batıya sefere çıkmasına, o arada Karadeniz'e yönelme imkânı vermiştir. Esasen Trabzon'un fethiyle doğu bölgeleri de dâhil Anadolu'nun Karadeniz kıyılarının tamamen kontrol altına alınması bu kıyılardan hareketle önemli bir ticari faaliyet alanı olan karşı kıyıları, bilhassa Kırım'ı ${ }^{10}$ önemli hale getirmişti. Aslında Kırım'ın kendi konumundan kaynaklanan Hindistan, Çin, Türkistan ve Sibirya'dan çeşitli emtiaları taşıyan yolların birleştiği bir mevkide bulunması da Kırım'ı önemli kılmaktaydı. Bunun dışında Karadeniz'e kuzeyden dökülen nehirler yoluyla en eski çağlardan beri yapılan ancak İslam fetihleri döneminde çok gelişen İskandinav ülkeleriyle ticaret de Kırım'ın murakabesi altındaydı. ${ }^{11}$ Haliyle bahse konu yarımada bu

Mihal oğlu Ali Bey sefere gönderilmiştir. Neticede hayli zamandır Osmanlı Devleti'nin fetihlerini de engelleyen bu gaileden tamamiyle kurtulmak için Fatih, kuvvetli bir ordu hazırlayarak Uzun Hasan'ın üzerine yürümüş lakin savaşacak düşmanı bulamamış yedi gün süren bir kovalamaca sonunda Otlukbeli denilen mevkide iki taraf karşı karşıya gelmiştir. Otlukbeli savaşıyla ilgili ayrıntılı bilgi için bkz; Salim Cöhce, "Otlukbeli Savaşına Kadar Akkoyunlular", Anadolu Birliğinin Sağlanmasında Otlukbeli Savaşının Yeri ve Önemi Panel Bildirileri, (nşr.,. E. Konukçu), Ankara 1997,s.125-135,; Akkoyunlu Devleti tarihi hakkında ayrıntılı bilgi için bkz., Ebu Bekr-i Tihrânî, Kitâb-ı Diyarbekriyye, (nşr., M. Öztürk), Ankara 2014.

8 İstanbul'da yaptırdığı hayratlar sebebiyle Gedikpaşa semtine adı verilmiştir. Ancak bu yapılardan kendi adını taşıyan hamamdan başka günümüze ulaşan olmamıştır. Askerlerinin kışlağı olması sebebiyle bir nevi gönül borcu ödemek maksatlı Afyon'da büyük bir külliye inşa ettirmiştir. Bununla birlikte Kütahya'da ilk hanımı Fahri Hatun'un türbesini yaptırmış ve Konya'daki Mevlevi tekkesini de tamir ettirmiştir. Ayrıntılı bilgi için bkz., Ahmet Topbaş, "Gedik Ahmet Paşa ve Vakfı", II. Vakıf Haftası (3-9 Aralık 1984) (Konuşmalar ve Tebliğler), Ankara 1985, s.179-181.

${ }^{9}$ Karamanoğullarının Osmanlılar ve diğer Türk siyasi teşekkülleriyle olan münasebetleri hakkında geniş bilgi için bkz., Y. Başkan, "Orta Anadolu'da Hâkimiyet Mücadelesi", (i.Ü. SBE, Basılmamış Doktora Tezi,) İstanbul 2007; Y. Başkan, "Karamanoğulları Beyliği", İnönü Ünv. SBE, Basılmamış Yüksek Lisans Tezi, Malatya 1999.

10 "Batı ve güneyden Karadeniz, doğu ve kuzeyden Azak deniziyle çevrilidir. Kıyıları girintili çıkıntılı olup yaklaşık 1000 kilometreyi bulur. Sahillerinin en mamur kısmı Kefe ile Akyar arasındaki kesimdir. Dağlık alanların üzerindeki yaylaların gerisinde ise düzlük bozkır kesimi bulunmaktadır." Bkz; DiA, XXV, s.447vd.

${ }^{11}$ Kuzey ülkelerinde etkin olan balıkçılık, köle ve kürk ticaret yolları ve Hindistan'dan gelen baharat ve Hazar sahilinden sevk edilen ipekler ilk akla gelenlerdir. Ayrıntılı bilgi

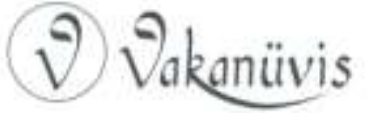


açıdan da önemli bir konuma sahip bulunuyordu. Ayrıca bu yarımada mümbit toprakları ve özellikle doğu Anadolu, İran ve Kafkaslardan Avrupa'ya geçişte sahip olduğu jeopolitik imkânlar da onu ön plana çıkarmaktaydı. ${ }^{12}$

Osmanlı Devleti'nin teşekkülü ve güçlü bir şekilde ortaya çıkmasından önce Venediklilerle Cenevizlerin rekabet sahası olan Kuzey Karadeniz kıyıları, özellikle Kırım, XIII. asrın ikinci yarısından itibaren Ceneviz ticaretinin merkez üssü haline gelmiş bulunuyordu. ${ }^{13}$ Ceneviz

için bkz; Mustafa L. Bilge, "Azak", DiA, IV, s.300; Selahattin Tansel, Fatih Sultan Mehmet'in Siyasi ve Askeri Faaliyetleri, İstanbul 1999, s.271.

12 “Kırım Yarımadası'nın en eski sakinleri İskitlerdir. M.Ö. 1250 yıllarından itibaren buraya yerleşen ve İskitlerin kolu olan Taurlardan sonra bölge Kimmerlerin saldırısına uğramıştır. Kırım sahilleri, M.Ö. Vı. yüzyıldan itibaren Yunan kolonilerinin hâkimiyetine girmiştir. Kırım'ın güneyine yerleşen Milet Kolonisi, kuzeyde hala varlığını sürdürmekte olan İskitlerle mücadele etmek zorunda kalmıştır. Sahil kesimleri M.Ö. I. yüzyıldan itibaren Roma hâkimiyeti dairesine girmiş, M.S. II. yüzyılda kuzeyden gelen Got kavimlerinin istilâsına maruz kalmıştır. M.S. dördüncü asrın son çeyreğinden itibaren Doğu Avrupa yönünde gelişen Hun istila hareketi, Kırım Yarımadasında da ciddi şekilde etkili olmuştur. Hun yayılması esnasında, "Don, Dinyeper aşağı mecrası ile Kırım ve Azak sahilleri Sarmat camiasına dâhil Alanlar ile meskûn bulunuyordu. Alanlar, III. asırda Soğdak ve Kefe şehirlerini zapt etmişlerdi. Hun İmparatorluğu'nun yıkılışından sonra, Kırım Yarımadası'nın doğu bölgeleri ve bilhassa Azak sahillerinde Bulgar ve Avar etkisinden bahsetmek mümkündür. Kırım'ın sahil kesimleri, M.S. VI. asırdan itibaren Bizans hâkimiyetine geçmiştir. Bizans nüfûzu sahil kesiminden öteye geçemezken, VII. Asırdan itibaren Hazar hâkimiyeti başlar. Hazarlar, VIII. yüzyılda sahil kesimine de hâkim olmuşlar, mezkûr tarihlerde bütün Kırım Yarımadası Hazar vilayeti haline gelmiştir. Hazar Hakanlığı'nın yıkılışından sonra da varlığını devam ettiren etnik ve kültürel unsurlar, Osmanlı dönemine kadar varlığını sürdürmüşlerdir. Hazarlar zamanında Musevîliği benimsemiş olan Karahim Türkleri, Kırım Yarımadası'nın aslî unsurları olmaya devam etmişlerdir. Hazarların yıkılışına müteakib, Kırım'da Peçenekler ve Kıpçaklar yerleşmişlerdir. Kıpçakların, Soğdak ve civarındaki sahil kesiminde de hâkim oldukları görülmektedir. Kalka muharebesinde Kıpçakları ağır bir yenilgiye uğratan Altınordu Devleti, sahil kesimi hariç, bütün Ceneviz, bozkır Kırım Yarımadası'na hâkim olmuştur. XIII. yüzyılda, Kırım Yarımadası'nın sahil kesimlerinde ise Altınordu hâkim olmuştur." Yücel Öztürk, Osmanlı Hâkimiyetinde Kefe (1475-1600), İstanbul 2014, s.13vd.

${ }^{13}$ Bizans'ın iç işlerinde göstermiş olduğu başarı sebebiyle Karadeniz'de ticari üstünlüğü kazanmışlardır. Ayrıca 1266 'da Altınorda Hanı Mangu Timur'dan Kefe'de ticaret yapmak için müsaade alıp, bu imtiyazlarla izin verilen bölgeleri tahkim edip surla çeviren Cenevizliler daha sonra bu sahillerde başka koloniler de meydana getirmişlerdir. Bkz., Halil İnalcık, "Kırım Hanlığı'nın Osmanlı Tabiliğine Girmesi ve Ahidname Meselesi", Belleten VIII/30, (Nisan 1944) s.194.

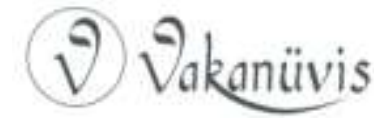


kolonileri bulundukları bölgenin hükümdarına belirli bir miktar gümrük vermek zorundaydı. Bu gümrük gelirini Kefe'deki Türk Devleti namına tudun adı verilen bir zabit kontrol edip toplardı. ${ }^{14}$

XIV. asrın ortalarından itibaren bölünmeye başlayan Altınorda Devleti'nin Azak Denizi çevresiyle Kuzey-Kafkasya ile Ten-Özi arasındaki bölgede ilk defa Kırım Hanlığı'nı kuran Hacı Gerey Han, gerek kaleleri gerekse silahları bakımından kendilerinden hayli üstün olan Cenevizlere karşı Sultan II. Mehmed'den yardım talebinde bulunmuştur. Bu talep Fatih'e aradığı fırsatı verecektir. Nitekim 1454'te Osmanlı Devleti ile Kırım Hanlığı arasında imzalanan anlaşmayla ${ }^{15}$ Cenevizler iyice köşeye sıkışmış bulunuyorlardı. ${ }^{16}$ Esasen İstanbul'un fethiyle birlikte Akdeniz ile bağlantıları kopmuş bir başka deyişle tamamen Osmanlı'nın kontrolüne geçmişti.

İleri görüşlü feraset sahibi bir hükümdar olan Fatih Sultan Mehmed'in uyguladığı genişleme siyaseti de dönemin şartlarını çok iyi takip edip en uygun zamanda harekete geçtiğini göstermesi bakımından önemlidir. ${ }^{17}$ Nitekim Kırım meselesinde de böyle olmuş ve Hacı Gerey Han'ın o sırada ölümü üzere başlayan taht mücadelesi Kırım'ın fethini zaruri hale getirmiştir. Hacı Gerey Han'ın ağabeyi Nur Devlet Han'ı Sikha'da oturmaya mecbur bırakan Mengli Gerey Han'ın tahta geçmesi de Fatih'i pek memnun etmemiş görünmektedir. Nitekim 1469'da Yakup Bey kumandasındaki Osmanlı donanmasının Ceneviz kolonilerini yağmaladığı gibi Han'ın bir kısım adamlarının da alınıp götürülmesi Mengli Gerey Han ile Fatih Sultan Mehmed arasındaki ilişkilerin kopmasına sebep olmuştur.

Mengli Gerey Han, Fatih Sultan Mehmed'e sitem dolu bir mektup yazarken, Osmanlı Sultanı'nın Kefe'deki Cenevizlilerin İstanbul'a ödediği haracı sekiz bin altına çıkarması da Karadeniz'de suların iyice

\footnotetext{
${ }^{14}$ Fahrettin Kırzıoğlu, Osmanlıların Kafkas Ellerini Fethi, Ankara 1998, s.52vd.

${ }^{15}$ Anlaşmanın kesin olarak varlığı bilinmemekle beraber Cenevizlerin Osmanlı ve Kırım Hanlığı askerleri tarafından kuşatıldığı bilgisi böyle bir anlaşmanın varlığını göstermektedir. Ayrıntılı bilgi için bkz., Selahattin Tansel, a.g.e., s.273.

${ }^{16} 18$ Nisan 1454 'de ayrıca Venediklilerle de bir ahidname imzalanmıştır. Ayrıntılı bilgi için bkz., Şerafettin Turan, Türkiye-italya iliş̧kileri I, s.468vd.

${ }^{17}$ Fatih Sultan Mehmed'in niteliklerine dair geniş bilgi için bkz., Halil İnalcık, "Mehmed II.", DIA, XXVIII, s.395-407: Feridun M. Emecen, Fetih ve Kıyamet, İstanbul 2013, s.82152.
}

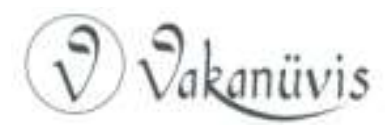


ısınmasına sebep olacaktır. Öyle ki Cenevizliler bu sefer de Mengli Gerey Han'a Osmanlı taraftarı olduğunu ve Fatih ile anlaştığını düşündükleri Kırım'ın Han'dan sonra en yetkilisi sayılan Kefe Tudunu Şirinli Eminek Bey'i azlettirdiler. ${ }^{18}$ Azlin ardından yerine önce KarayMirza, daha sonra Sartak Bey Kefe Tudunu olmuştur. Bu olaydan sonra Kırım'ın önde gelen Boybeyleri Eminek Bey etrafında toplanmaya başlamışlar ve Mengli Gerey Han'a başkaldırarak onun Cenevizlere sığınmasına sebep olmuşlardır. ${ }^{19}$

Uzun bir süredir sabırla doğru zamanı bekleyen Sultan II. Mehmed için fetih vakti Eminek Bey önderliğinde girişilen isyanda kendisinden istenilen yardımla geldi. Çünkü şehri muhasara etmek isteyen Eminek Bey kendisine bağlı kuvvetlerle Kefe Cenevizlilerine sığınan Mengli

\footnotetext{
18 'Şirin Beyi Mamak 1473'de ölmüş ve yerine adet olduğu veçhile Kefe Konsüllüğü müşavirleri ile dört azadan mürekkep fizodellâ compagna ile de mutabık kalındıktan sonra Mamak'ın biraderi Eminek Mirza, Kefe tudunu seçilmişti. Fakat kısa bir müddet sonra Mamak'ın oğlu Sartak annesinin de yardımı ile amcasına karşı cephe almış ve Kefe Tudunluğunu ele geçirmek üzere entrikalar çevirmeye başlamıştı. Diğer taraftan Eminek'in Osmanlı İmparatorluğu ile gittikçe artan dostane münasebeti karşısında endişe duyan ve zaten Sartak'dan da bir hayli rüşvet almış olan Cenevizliler, Han'a müracaatla, Eminek'in azl ve fakat Sartak'ı değil Karay Mirza'yı Tudun nasb etmekle bir dereceye kadar müsbet bir şekilde Halletmek istediyse de Cenevizliler Sartak'ın tudun olması mevzuunda şiddetle ısrar ettiklerinde [hatta Cenevizli memurlardan biri Han'ı t utsak ettikleri dört kardeşini salıvermekle tehdit etmiştir. Ayrıntılı bilgi için bkz. Halil İnalcık, s.205] Karay Mirza'yı da azlederek bi'l-mecburiye bu mevkie Sartak'ı getirdi." [Bkz., A. Süha Arslangiray, Kırım Hanlığı Menşei- Kuruluşu ve Osmanlı Imparatorluğu'na Bağlanması, İstanbul 1959, s.52vd] “Fatih Sultan Mehmet, Trabzon'dan Kefe'ye kaçmış olan birkaç köleyi istemek üzere oraya bir elçi göndermişti. Bu Elçi, Fatih tarafından verilecek herhangi bir vazifeyi kabule, Eminek Bey'i ikna etti. Hadiseyi duyan Cenevizliler Eminek'i öldürmek istemişler ise de muvaffak olamamışlardı." Bkz.,Selahattin Tansel, a.g.e., s.274vd.

${ }^{19}$ Son Kırım hanı Şahbaz Giray'ın oğlu Halim Giray tarafından 1811'de kaleme alınan Gülbün-ü Hânân adlı eserde Hacı Gerey Han'ın vefatı akabinde üç ay tahtta kalabilen Mengli Grey Han daha sonra Nur devlet Han'ın isyanı sebebiyle canını kurtarmak için Menkub kalesinde Cenevizlilere iltica etmek zorunda kalmış, Şirin ümerasından sadık emiri Eminek'in ise kendisini kurtarmak için Fatih Sultan Mehmed'i davet ettiğini bildirmektedir. [Bkz., Halim Giray, Gülbünü Hânân, İstanbul 1874, s.8] Ayrıca Cevdet Paşa'nın yine bu eserden derlediği Kırım ve Kafkas Tarihçesi adlı eserinde ise Mengli Gerey Han'ın üç ay tahtta kaldıktan sonra emmizâdeleri tarafından tahttan indirildiği, akabinde ise Eminek ve diğer kendisini destekleyen emirler sayesinde yeniden tahta çıktığı ve emmi zadelerine güvenmedi için beylerine danışarak Kefe ve Menkub kaleleri fethi için Fatih Sultan Mehmed'ten yardım istenildiği zikredilmektedir. Bkz., Cevdet Paşa, Kırım ve Kafkas Tarihçesi, İstanbul 1890, s.13vd.
}

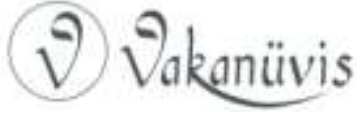


Gerey Han'a karşı mukavemet gösterebilecek durumda değildi. Nitekim Fatih bu çağrıyı dikkate alarak hemen Gedik Ahmed Paşa'yı Kırım seferine memur edecektir. ${ }^{20}$

Ahmed Paşa üç yüz gemi hazırlatıp ${ }^{21}$ atlı, yaya seçkin askerlerden teşekkül eden bir ordu hazırlayarak seferin nereye yapılacağından habersiz bir şekilde Sultan'ın emrini beklemeye başlamıştır. Takriben yetmiş bin kişilik bu ordu verilen emir doğrultusunda Kırım'a hareket edecek ve Kefe limanına ulaşır ulaşmaz harekete geçecektir. Türk fetih geleneği ve cihâd anlayışının bir tezahürü olarak Gedik Ahmed Paşa öncelikle şehrin teslimini teklif etmişse de ret cevabı almıştır. Askeri yaptığı konuşmayla galeyana getiren Gedik Ahmed Paşa orduyla birlikte Cenevizlilere rahat vermemiştir. Nitekim savaşın üçüncü günü Türk ordusu ve komutanının namını bilen hisar ahalisi tekfurlarına ${ }^{22}$ teslim olmalarının kendileri ve aileleri için daha iyi olacağını teklif etmek zorunda kalmıştı. Bunun üzerine Cenevizli yönetici aman dileyerek kaleyi teslim etti. Ahmed Paşa da aman verdi ve beşinci gün, yani 9 Haziran 1475 günü kapılar açıldı. Şehir Osmanlı kuvvetlerine teslim oldu.

\footnotetext{
${ }^{20}$ Anonim Tevârîh-i Âl-i Osman, (nşr., N. Azamat), İstanbul 1992, s.117; Müneccimbaşı Ahmed b. Lütfullah, Camiü'd-Düvel, (nşr., A. Ağrıdıkça), İstanbul 1995, s.288vd.; Âşık Paşazâde, a.g.e., s.266; Neşrî, a.g.e., s. 823; Hadîdî, a.g.e., s.295; Tursun Bey, a.g.e., s.169; Oruç Bey, a.g.e., s. 131vd.; Hoca Sadettin Efendi, a.g.e., s. 148vd: İdris-i Bitlisî, a.g.e., s. 236; Hasan Rumlu, Ahsenü't-tevârîh, (nşr., M. Öztürk), Ankara 2006, s.530.] Dönemin ana kaynakları arasında olmasına rağmen Karamanî Mehmed Paşa'nın tarihinde Kefe fethinde Gedik Ahmed Paşa'nın adı geçmemektedir. Hatta fetihleri Gedik Ahmed Paşa ile özdeşleşen Alaiyye ve Karaman fetihlerinde de bahsi geçmemektedir. Bunun sebebi Mehmed Paşa ile Ahmed Paşa arasındaki rekabetten ileri gelmektedir. Bkz., Karamanî Mehmed Paşa, Tevârîhü's-Selâtînü'l-Osmâniye, (nşr., Konyalı Ibrahim Hakkı), İstanbul 1947.

${ }^{21}$ Bu hususta kaynaklara arasında ihtilaf bulunmaktadır ki, İdris-i Bitlisî, Hasan Rumlu ile Gelibolulu Mustafa Ali eserlerinde bu sayıyı "iki yüz gemi” olarak vermektedirler. Bkz., İdris-i Bitlisî, a.g.e., s. 236; Hasan Rumlu, a.g.e., s. 530; Gelibolulu Mustafa Ali, Künhü'l-Ahbâr C.II: Fatih Sultan Mehmet Devri 1451-1481, (nşr., M.H. Şentürk) Ankara 2003, s.164vd.

${ }^{22}$ Osmanlıların bu seferi sırasında Kefe Hisarı Cenevizli bir tekfur tarafından yönetiliyordu. Bkz. Âşık Paşazâde, a.g.e., s.265: Neşrî, a.g.e., s.823.
}

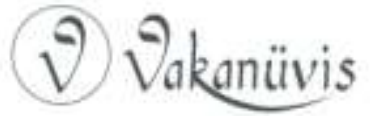


Klasik Osmanlı fetih siyaseti bu hisarda da belirgin şekilde kendisini göstermektedir. ${ }^{23}$ Zira Cenevizlilerden yeniçeri ocağına bin beş yüz er alındığı gibi kırk bin kişi de göçe tabi tutularak İstanbul'a sevk edildi. ${ }^{24}$ Arkasından fethedilen bu bölgenin tahriri alındı. ${ }^{25}$

Kefe'nin zaptından sonra, Cenevizliler tarafından hapse atılmış olan Mengli Gerey Han, Gedik Ahmed Paşa tarafından zindandan çıkarılmış ve bu sahillerin mukadderatı üzerinde Han'la bir anlaşma yapılmıştır. 1475 yılından itibaren Kırım'ın Osmanlı Devleti yüksek hâkimiyetine girdiği söylenebilir. Çünkü gerek Mengli Gerey Han mevkiini muhafaza etmek için Kırım boy beylerinekarşı güçlü bir Osmanlı desteği istemekte, boy beyleride kendi arzularını hesaba katan bir hanın üstünde bir devletin metbuluğunu daha efdal görmekte ve diğer bir taraftan ahalinin çoğunluğu da siyasi otoritelerin çekişmelerinden usanmış ve bu kudretli metbu kabul etmeğe dünden razı idi. Neticede Kırım Hanlığı, Osmanlı Devleti yüksek hâkimiyetine girerek Lehistanve

${ }^{23}$ Ahmed Paşa gazilere hilat giydirdi. Âlimler ve dervişlere bağışlarda bulundu. Ahmed Paşa, yanına gelen tekfuru tuttu, hazinesine el koydu ve padişahın hazinesine kattı. Şehrin halkını sınıflandırarak kayda geçirdi. Zenginlerini, fakirlerini, mallarını, oğlanlarını, kızlarını, askerlerini ayrı ayrı kaydettiler. Bu halktan ve mallardan padişaha layık olanları aldılar, yerinde bırakılması gerekenlere dokunmadılar. Askerlerini sürüp evlerinden çıkardılar ve onların evlerini gazilere verdiler." Bkz., Âşık Paşazâde, a.g.e., s. $265 \mathrm{vd}$.

${ }^{24}$ Selahattin Tansel, a.g.e., s. 277: İbn Kemal, s.386. İstanbul'a gönderilenler arasında fetihten sonra oğluyla birlikte Mengli Giray'ın da olduğu söylenir. Bu konu Kırım Hanlığı ile alakalı meselelerin en müphemi olmak bakımından önemlidir. H. İnalcık ve Ş. Turan bu mesele üzerinde hayli çalışmışlarsa da mesele hala netlik kazanmış değildir. Ayrıca İstanbul'a gönderilenlerle alakalı olarak Hammer'in Osmanlı tarihinde "fetihten sekiz gün sonra Ahmed Paşa Ermeni ahaliden İskoer Çiafiko'ya ve onunla müttefîken şehri kendisine teslim eden başlıca itibarlı kişilere büyük bir ziyafet çekti. Ziyafetin sonunda vezîr-i âzâm misafirlerine ruhsat verdi: ziyafet mahallinin kapısı -ancak bir kişinin geçmesine müsait bir şekilde- dar bir merdivene açılıyordu. Merdivenin son basamağında duran cellâd, merdivenden inenlerden her birinin boynunu kesdi; yalnız Çeafiko Kostantiniyye'de idam edilmek üzere alıkonuldu." bilgisi Osmanlı kaynaklarında geçmemekle beraber Hammer dipnotta "Cenova Vekayinamesi"ni kaynak olarak vermiştir. Bkz., Hammer II, s.126.

${ }^{25}$ Kefe'nin fethedilmesinin hemen akabinde tahririnin yapıldığı kaynakların ittifakı ile sabit ise de bu defter günümüze ulaşamamıştır. Kırım Hanlığı'na ait Başbakanlık Osmanlı Arşivindeki tek tahrir defteri ise 1128/1715 yılına ait olup onun da eksik kısımları mevcuttur.Bkz.,Başbakanlık Osmanlı Arşivi Rehberi, İstanbul 2010, s.51.

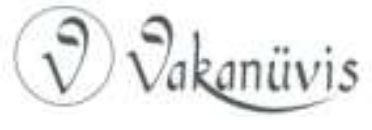


Cenevizler arasında kaybolup gitmekten kurtulmuş dolayısıyla varlığını üç asır daha devam ettirebilmişlerdir.

Kefe'nin fethin akabinde Ahmed Paşa komutasındaki Osmanlı ordusu Azak, Yabugermen üzerinden Çerkez iline kadar olan bütün kaleleri ele geçirmiştir. Daha sonra Menkub hisarı üzerine gidilmiş, tekfur teslim olsa da O'nun yakınlarından biri kale kapılarını kapatıp muharebeye girişmiştir. Ahmed Paşa hisarın cenkle alınamayacağını anlayınca geri çekilip pusuya yatmış buna inanılarak kapılar açılınca da Osmanlı askerleri hisara girerek fethi müyesser kılmıştır. Kefe'de olduğu gibi burada da klasik fetih siyaseti uyguland.. ${ }^{26}$ Böylece Gedik Ahmed Paşa, Kırım yarımadasındaki başarılı faaliyetleriyle Fatih Sultan Mehmed'in Karadeniz'in bir Türk gölü haline getirilmesi planını büyük ölçüde tamamlamıştır.

\section{Kaynakça}

Ahmet Cevdet Paşa, Kırım ve Kafkas Tarihçesi, İstanbul 1890.

Anonim, Tevârih-i Âl-i Osman, (nşr. Nihat Azamat), İstanbul 1992.

Arslangiray, A. Süha, Kırım Hanlığı Menşei-Kuruluşu ve Osmanlı imparatorluğu'na Bağlanması, İstanbul 1959.

Âşık Paşazâde, Osmanoğulları Tarihi, (nşr. Kemal Yavuz, Yekta Saraç), istanbul 2003.

Başkan, Yahya, Karamanoğulları Beyliği, İnönü Üniversitesi Sosyal Bilimler Enstitüsü, Basılmamış Yüksek Lisans Tezi, Malatya 1999.

Başkan, Yahya, Orta Anadolu'da Hâkimiyet Mücadelesi, ìstanbul Üniversitesi Sosyal Bilimler Enstitüsü, Basılmamış Doktora Tezi, İstanbul 2007.

Bıjışkyan, P. Minas, Karadeniz Kıyıları Tarih ve Coğrafyası, (nşr. Hrand Andreasyan), İstanbul 1969.

Bilge, Sadık Müfit, Osmanlı Çağı'nda Kafkasya 1454-1829 (Tarih-ToplumEkonomi), İstanbul 2015.

Cöhce, Salim, "Otlukbeli Savaşına Kadar Akkoyunlular", Anadolu Birliğinin Sağlanmasında Otlukbeli Savaşının Yeri ve Önemi Panel Bildirileri, (Hzl. Prof. Dr. Enver Konukçu), Ankara 1997, s.125-135.

Danişmend, ì. Hami, İzahlı Osmanlı Tarihi Kronolojisi, İstanbul 1971.

26 Âşık Paşazâde, a.g.e., s.266vd.; Neşrî, a.g.e., s. 827vd.; Tursun Bey, a.g.e., s.170; ỉbn Kemal, a.g.e., s. 387.

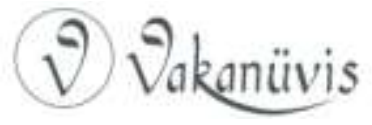


Ebu Bekr-i Tihrânî, Kitâb-ı Diyarbekriyye, (nşr., Mürsel Öztürk), Ankara 2014.

Gelibolulu Mustafa Ali, Künhü'l-Ahbâr, c. II: Fatih Sultan Mehmet Devri 1451-1481, Ankara 2003.

Hadîdî, Tevârih-i Âl-i Osman, (nşr. Necdet Öztürk) İstanbul 1991.

Halim Giray, Gülbün-ü Hânân, İstanbul 1874.

Hammer, Joseph von, Büyük Osmanlı Tarihi, İstanbul 2000.

Hammer, Joseph von, Kırım Hanlığı Tarihi, İstanbul 2013.

Hasan Rumlu, Ahsenü't-Tevârîh, (nşr. Mürsel Öztürk) Ankara 2006.

Heyd, W., Yakın-Doğu Ticaret Tarihi, (nşr. E.Z. Karal), Ankara 2000.

Hoca Sadettin Efendi, Tacü't-Tevarih, (nşr. İsmet Parmaksızoğlu) Ankara 1992.

Hülagü, M. Metin, "Kırım Hanlığının Kuruluşu ve Türk-Rus iliş̧kilerindeki Yeri(1441-1783)", Uluslararası Türkoloji Sempozyumu, TiKA (Türk İşbirliği ve Kalkınma İdaresi Başkanlığı), 31 Mayıs-4 Haziran 2004, Simferepol, Ukrayna, Kırım.

İbn Kemal, Tevârih-i Âl-i Osman, (nşr. Şerafettin Turan) Ankara 1991.

İdris-i Bitlisî, Heşt Behişt VII. Ketibe:Fatih Sultan Mehmed Devri, 14511481, (nşr., Muhammed ibrahim Yıldırım), Ankara 2013.

İnalcık, Halil, "Kırım Hanlığı", DiA, İstanbul 2013.

İnalcık, Halil, "Gedik Ahmed Paşa", DiA, İstanbul 2013.

İnalcık, Halil, "Mehmed II", DiA, İstanbul 2013.

İnalcık, Halil, "Yeni Vesikalara Göre Kırım Hanlığı'nın Osmanlı Tabiliğine Girmesi ve Ahidname Meselesi", Belleten VIII/30, Nisan 1944.

İnalcık, Halil, Kuruluş Dönemi (1302-1481) Osmanlı Sultanları, İstanbul, 2011.

Karamanî Mehmed Paşa, Tevârîhü's-Selâtînü'l-Osmâniye, (nşr. Konyalı İbrahim Hakkı), İstanbul 1947.

Kırzıoğlu, Fahrettin, Osmanlıların Kafkas Ellerini Fethi, Ankara 1998.

Kıvamî, Fetihnâme, (nşr. Ceyhun Vedat Uygur), İstanbul 2007.

Mehmet Süreyya Efendi, Sicill-i Osmânî Yahud Tezkire-i Meşâhir-i Osmâniyye, (nşr., A. Yuvalı, A. Aktan, M. Keskin) İstanbul 1995.

Müneccimbaşı, Camiü'd-Düvel, (nşr., A. Ağrıdıkça), İstanbul 1995.

Neşrî, Kitâb-ı Cihan-Nüma, (nşr. M. Altay Köymen, Faik Reşit Unat,) Ankara 1995.

Oruç Bey, Tevârîh-i Âl-i Osmân,(nşr. Necdet Öztürk), İstanbul 2008.

Öztürk, Yücel, Osmanlı Hâkimiyetinde Kefe (1475-1600), İstanbul 2014.

Reindl, Hedda, II. Bayezid ve Çevresi, (nşr. Ali Suat Ürgüplü) İstanbul 2014.

Sümer, Faruk, "Uzun Hasan", DiA, İstanbul 2013.

Tansel, Selahattin, Sultan Mehmet'in Siyasi ve Askeri Faaliyetleri, İstanbul 1999.

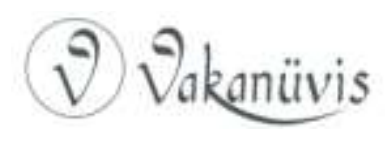


Tellioğlu, ỉbrahim, Tarih Boyunca Karadeniz, Trabzon 2015.

Tezcan, Mehmet, Klasik ve Ortaçağ Dönemlerinde Karadeniz ve Kafkasya, Trabzon 2012.

Topbaş, Ahmet, "Gedik Ahmet Paşa ve Vakfı", II. Vakıf Haftası (3-9 Aralık 1984) (Konuşmalar ve Tebliğler), Vakıflar Genel Müdürlüğü Yayınları, Ankara 1985, s.179-181.

Tursun Bey, Târih-i Ebu'l-Feth, (nşr. M. Tulum) İstanbul 1974.

Uzunçarşılı, I. Hakkı, "Otranto Zaptından Sonra Napoli Kralı ile Dostluk Görüşmeleri", Belleten XXV/100, Ekim 1961.

Uzunçarşılı, I. Hakkı, Büyük Osmanlı Tarihi, Ankara.

Uzunçarşıll, I. Hakkı, "Değerli Vezir Gedik Ahmed Paşa II. Bayezid Tarafından Niçin Katledildi?", Belleten XXIX/115, Temmuz 1965.

Ülküsal, Müstecib, Kırım-Türk Tatarları, İstanbul 1980.

Ürekli, Muzaffer, Kırım Hanlığının Kuruluşu ve Osmanlı Himayesinde Yükselişi: 1441-1569, Ankara 1989.

Yinanç, Mükrimin Halil, "Ahmed Paşa, Gedik" IA., I, Eskişehir 1997, s. 193199. 